\title{
部分領域分割を伴う境界要素法のアダプティブ要素*
}

\author{
神 谷 紀 生*1, 小 出 征 史*2
}

\section{Adaptive Boundary Element for the Problem with Subregion Partition}

\author{
Norio KAMIYA and Masafumi KOIDE
}

\begin{abstract}
The sample point error analysis and the related adaptive boundary refinement, proposed by one of the present authors, are extended to problems with subregion partition, which is often required for higher accuracy and for dissimilar materials. Interface between the two subregions should be discretized to raise accuracy of the entire calculation by the boundary integral equations for each subregion combined by using the compatibility and equilibrium conditions. A parameter regularizing the difference between influene of the boundary error is introduced. Two examples are tested to verify the availability of the proposed method.
\end{abstract}

Key Words: Boundary element method, Error analysis, Adaptive element, Sample point error analysis.

1 はじめに

境界要素法 ( BEM)、有限要素法 (FEM) はその解析 対象の境界すしくは領域を有限の要索で近似する睛散 化手法である。そのため要分割は直接、数值解の精度 に大きな影整を与える。近年、道切な要釜割に関する 研究はFEMにおいてはかなりの発展がみられ、誤差評 価手法を用いたアダプティブ要素分割手法が確立しつつ あり、一部市販ソフトが実用に至ろうとしている。

BEM は、境界皘分方程式が境界上の通点において成 り立つとして問題を扱う。しかる、㕕く用いられる直接 法の定式化によれば、次元の異なる量を未知数にとって いる。境界要素を用いて噰散化し、代数方程式を得るプ ロセスはFEM と似ているが、上記のような定式化に基 づいているために、FEMに比べ、譟差解析やその評価 が困難になっている。BEMのアダプティブ要索に関して は、比较的最近になって始められたが、決定的な器差解 析法や要索分割法は数学的にも寒用的にも確立されて いない[1] [6]。著者の一人らは、BEMの上記の原理によ

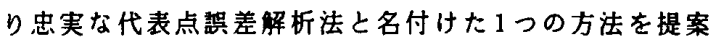
した[7][8]。

BEMにおいては、解析対象が異理材料の組み合わせ から成るとき、あるいは精度向上のために、解析対象を いくっかの部分領域に分割して解析する必要のある場 合がある。そこで本研究では、代表点誤差解析法によ
り、2領域からなる解析対象に対するアダプティブ要素 を櫣成する方法を示す。代表点誤差解析法は誤差の影慗 度に基づいて要素分割を行う方法であるから、内部境 界における扱いを新たに考虑する。解析例題によりそ の有勃性を確かめる。

\section{BEMのフタフフティブ要来}

BEM のアダプティブ法に関する従来の研究と代表点 誤差解析法について概略をここで示しておく。

\subsection{BEMのTタプティフ法}

BEM のアダブティブ法のおもな研究には、次のような ものが知られている。Alarcon ら $\check{b}^{[1]}$ は、積分方程式の残 差を利用してある種の誤差ノルムを定め、階層的多項式 で要索の次数をあげる $\mathrm{p}$ 法を提案している。Rencis ら ${ }^{[2]}$ および佐々木ら ${ }^{[4]}$ は、解の精度が要素の寸法に特定の関 連があるものとして、要菜を細分化するh 法を用いて いる。また Rank ${ }^{\left[{ }^{3}\right]}$ 仙、選点以外での積分方程式の残差 により抧差のノルムを定義し、FEM で用いられている あのと同様な解の高精度化を、h法およびhと $\mathrm{p} の$ 組み 合わせであるh-p 法を提案している。以上の手法はい ずれる、FEMで用いられている方法を BEMに流用し ており、そのまま BEMに適用できるかどうか疑問が残 る。これに対し、結城ら ${ }^{[5]}$ は、ソース点を境界上と外部

* 原稿受付 平成 4 年 7 月 15 日.

*1 正員, 名古屋大学工学部( 464-01 名古屋市千種区不老 町).

*2 学生員, 名古屋大学大学院. 
にとって得られる解の差に注目し、誤差を定義すること によってh法によるアダプティブ法の研究を進めている。 この手法は、領域外のソース点の配置の決定が難しい。 Guiggiani ${ }^{[6]}$ は、二次要素の本来要素の中央にとられる中 間節点を少しだけずらして、二通りの解を算出し、それ らの解の差をとる手法を提案している。この方法は効 率よく誤差を計算できる利点があるが、正しい解の推 定という意味で問題を残している。さらに以上述べた 方法[2] [6] は次元の異なる誤差を扱わなければならない という難点を持っている。

そこで川口ら $ら^{[7][8]}$ は、初期選点以外に選点 (代表点) をとり、そこで境界積分方程式が成り立っための各要索 上における修正量を算出し、それをもとに誤差評価を 行なう代表点誤差解析法を提案した。この手法は直接 法による BEM の特徵をふまえ、次元の異なる量を統一 的に扱えるという利点がある。部分領域分割を含む解 析対象に代表点誤差解析法を拡張するまえに、その理 諭の概要を述べる。

\section{2 代表点竞差解析法}

BEM は、境界上のいくつかの選点において積分方程 式を満足させる選点法によっている。したがって、境界 上の選点以外においては積分方程式は満足されないこ とになる。今、2次元空間の領域を几とし、ポテンシャル uおよびフラックスqが指定される境界をそれぞれ「、、 $\Gamma_{q}$ とするラブラス方程式の境界值問題は、次のように積 分方程式で表示される。

$$
\left.\begin{array}{c}
c\left(p_{i}\right) u\left(p_{i}\right)=\int_{\Gamma}\left[q\left(p_{j}\right) u^{*}\left(p_{i}, p_{j}\right)-u\left(p_{j}\right) q^{*}\left(p_{i}, p_{j}\right)\right] d \Gamma \\
u=\bar{u}\left(\text { on } \Gamma_{u}\right), q=\bar{q}\left(\text { on } \Gamma_{q}\right)
\end{array}\right\}
$$

ここで、cはンース点 $p_{i}$ の位置に関連して決まる定数、 $p_{j}$ は積分点である。また $u^{*} 、 q^{*}$ はラプラス方程式の基本

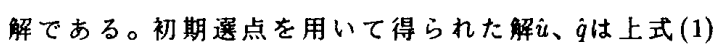
を満足するが、初期選点以外の点を代表点 $p_{i}^{\prime}$ とすれば、 $\hat{u} 、 \hat{q}$ はその点で積分方程式を満たさない。そこで、 おいて、皘分方程式を満足するようにu、 $\hat{q} に$ 修正量 $e_{\boldsymbol{u}}$ と $e_{q}$ を加える。

$$
c_{i}\left(p_{i}^{\prime}\right)\left\{\hat{u}\left(p_{i}^{\prime}\right)+e_{u}\left(p_{i}^{\prime}\right)\right\}=\int_{\Gamma}\left[\left(\hat{q}+e_{q}\right) u^{*}-q^{*}\left(\hat{u}+e_{u}\right)\right] d \Gamma
$$

積分方程式 (2)の左辺は、 $\hat{u} 、 \hat{q} の$ 内掩加得られる量と の間に次のような不整合量が生じる。フラックス指定境 界 $\Gamma_{q}$ 上では、

$$
\begin{aligned}
r\left(p_{i}^{\prime}\right) & \equiv c_{i}\left(p_{i}^{\prime}\right)\left\{\hat{u}\left(p_{i}^{\prime}\right)-\dot{u}_{i}\left(p_{i}^{\prime}\right)\right\} \\
& =\int_{\Gamma_{u}} e_{q} u^{*} d \Gamma-\int_{\Gamma_{q}} e_{u} q^{*} d \Gamma-c_{i}\left(p_{i}^{\prime}\right) e_{u}\left(p_{i}^{\prime}\right)
\end{aligned}
$$

ここで、 $c_{i} \dot{u}_{i}\left(p_{i}^{\prime}\right)$ は近似解 $\hat{u} 、 \hat{q}$ を用いて計算される代表点 での値である。

$$
c_{i} \dot{u}_{i}\left(p_{i}^{\prime}\right) \equiv \int_{\Gamma}\left(\hat{q} u^{*}-q^{*} \dot{u}\right) d \Gamma
$$

$p_{i}^{\prime}$ がポテンシャル指定境界 $\Gamma_{u}$ 上に存在する時は、式(2)の 左辺に㚝正量を加味する必要がないために次式となる。 $r\left(p_{i}^{\prime}\right) \equiv c_{i}\left(p_{i}^{\prime}\right)\left\{\bar{u}\left(p_{i}^{\prime}\right)-\dot{u}_{i}\left(p_{i}^{\prime}\right)\right\}=\int_{\Gamma_{u}} e_{q} u^{*} d \Gamma-\int_{\Gamma_{i}} e_{u} q^{*} d \Gamma(5)$ 式(3)および式(5)は、左辺に与えられる不整合量を要 素上の正量 $e_{u} 、 e_{q}$ と関連づけている。要菜上の $e_{u}$ と $e_{q}$ の分布は未知であるので、これを要素座標によっって次 のようにモデル化する。要索うにおいて

$$
\left.\begin{array}{l}
e_{u}=e_{u j} \Psi(\xi) \\
e_{q}=e_{q j} \Psi(\xi)
\end{array}\right\}
$$

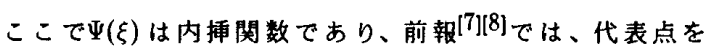
要素中央にとることと関連して、次のような関数を用 いた。

$$
\Psi(\xi)=\left\{\begin{array}{lc}
(1+\xi) & (-1 \leq \xi \leq 0) \\
(1-\xi) & (0 \leq \xi \leq 1)
\end{array}\right.
$$

したがって要类端点の初期節点では修正量が 0 となる。 式(6)を式(3)および式(5)に代入し、部散化を行うと、 $\underline{p_{i}^{\prime} \in \Gamma_{q}}$

$$
r\left(p_{i}^{\prime}\right)=\sum_{j}^{n_{u}} \int_{\Gamma} u^{*} \Psi e_{q j} d \Gamma-\sum_{j}^{n_{q}} \delta_{i j} c_{i} e_{u i}-\sum_{j}^{n_{q}} \int_{\Gamma} q^{*} \Psi e_{u j} d \Gamma \quad 8
$$$$
\underline{p_{i}^{\prime} \in \Gamma_{u}}
$$

$$
r\left(p_{i}^{\prime}\right)=\sum_{j}^{n_{*}} \int_{\Gamma} u^{*} \Psi e_{q j} d \Gamma-\sum_{j}^{n_{q}} \int_{\Gamma} q^{*} \Psi e_{u j} d \Gamma
$$

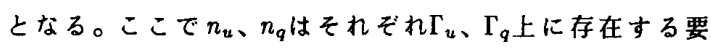
䒺の数である。即ち $j \supseteq i(i=1, \cdots, N) て ゙ 、 N=n_{u}+n_{q}$ は 全要素数である。

$$
\text { 式(8)および式(9)をマトリクス形式で害くと }
$$

$$
r=A e
$$

となる。左辺の代表点不整合量ベクトルは容易に求め られることができるから、これを用いて、この連立代数 方程式(10)を解くことにより要菜誤差のベクトルを計 算することができる。

代表点詋差解析法では、式(10)で得た修正量をると に、以下で述べる条件を満たすとき代表点て要素を 2 分 割するh法により細分割を行う。 $e_{u}$ と $e_{q}$ は次元が異なる ので、この修正量(誤差)を統一的に扱うために、誤差影 㮩マトリクスAに含まれる、それぞれの誤差に対応する 基本解を掛け合わせた量を拡張䛊差表示式と定義し、そ れを用いることにする。式(8)(9)より、

$$
r\left(p_{i}^{\prime}\right)=\sum^{N}\left[\tilde{e}_{q[i, j]}+\tilde{e}_{u[i, j]}\right]
$$


ここでAの成分 $a_{i}$ により

$$
\left.\begin{array}{l}
\tilde{e}_{q[i, j]}=a_{i j} e_{q j} \\
\tilde{e}_{u[i, j]}=a_{i j} e_{u j}
\end{array}\right\}
$$

拡張誤差表示式の䑨対値ノルムを

$$
\eta_{i j} \equiv\left|\tilde{e}_{q[i, j]}\right|+\left|\tilde{e}_{u[i, j]}\right|
$$

で定義し、 $\eta_{i j}$ の平均は次式で表す。

$$
\eta_{\text {ave }}=\frac{1}{N^{2}} \sum_{i}^{N} \sum_{j}^{N} \eta_{i j}
$$

次の判定基準を満たす $j$ 要素を $\mathrm{h}$ 法により、2 分割するこ とにより、細分化を実行する。

$$
\eta_{i j}>\eta_{a v e}
$$

以上が代表点誤差解析法によるアダブティブ法である。

\section{3 部分領城を含む代表点祝差解析法}

図1のように、異なる材質からなる2次元空間の領域

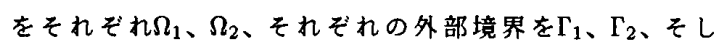
て内部境界を程とし、ラプラス方程式の境界值問題を考 える。

$$
\begin{array}{ccc}
\text { 支配方程式 } \left.\begin{array}{cc}
\mu_{1} \nabla^{2} u=0 & \text { (in } \left.\Omega_{1}\right) \\
\mu_{2} \nabla^{2} u=0 & \left(\text { in } \Omega_{2}\right)
\end{array}\right\} \\
\text { 境界条件 } \left.\quad \begin{array}{ll}
u=\bar{u} & \left(\text { on } \Gamma_{1 u}, \Gamma_{2 u}\right) \\
q=\bar{q} & \left(\text { on } \Gamma_{1 q}, \Gamma_{2 q}\right)
\end{array}\right\}
\end{array}
$$

この境界值問題の境界積分方程式はそれぞれの領域に ついて、

$\underline{o n \Gamma_{1} \cup \Gamma_{I}}$

$c\left(p_{1 i}\right) u^{1}\left(p_{1 i}\right)=\int_{\Gamma}\left\{q^{1}\left(p_{1 j}\right) u^{1 *}\left(p_{1 i}, p_{1 j}\right)-q^{1 *}\left(p_{1 i}, p_{1 j}\right) u^{1}\left(p_{1 j}\right)\right\} d \Gamma$

\section{$\underline{o n} \Gamma_{2} \cup \Gamma_{I}$}

$c\left(p_{2 i}\right) u^{2}\left(p_{2 i}\right)=\int_{\Gamma}\left\{q^{2}\left(p_{2 j}\right) u^{2 *}\left(p_{2 i}, p_{2 j}\right)-q^{2 *}\left(p_{2 i}, p_{2 j}\right) u^{2}\left(p_{2 j}\right)\right\} d \Gamma$

となる。ここで、右肩の添え字 $1 、 2$ はそれぞれ領域 $\Omega_{1}$ 、 $\Omega_{2}$ に関連することを示す。 $u^{k} 、 q^{k}(k=1,2)$ は境界におけ

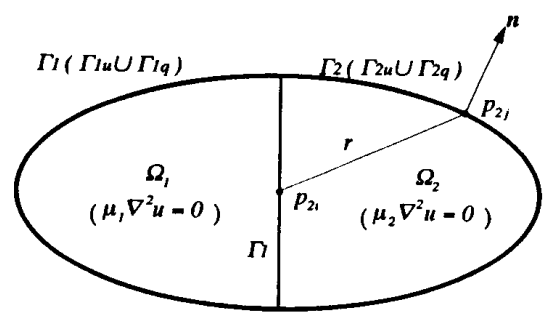

图1. 2 領域部分分割
るポテンシャル值及びフラックス值、 $p_{k i}$ はンース点、 $p_{k}$ は皘分点を表す。 $c$ はソース点 $p_{k i}$ の位置により定まる定 数であり、

$$
c=\frac{\theta}{2 \pi} \quad\left(p_{k i} \in \Gamma_{k} \cup \Gamma_{I}, \theta: \text { 内角 }\right)
$$

さらに $u^{k *} 、 q^{k *}(k=1,2)$ は基本解であり、2 次元ラプラ ス方程式については

$$
\left.\begin{array}{c}
u^{k *}=\frac{1}{2 \pi} \ln \frac{1}{r} \\
q^{k *}=-\frac{1}{2 \pi r} \frac{\partial r}{\partial n}
\end{array}\right\}
$$

となる。rは点 $p_{k i}$ と点 $p_{k j}$ の距離であり、nは $p_{k j}$ における 単位法楾ベクトルである。

式（17）おょび(18)を境界の点 $p_{k i}$ について、境界值を 低次の内㨉関数で近似することにより雕散化し、マト リクス形式で表示すると、

$$
\boldsymbol{H}^{k} \boldsymbol{u}^{k}=G^{k} \boldsymbol{q}^{k} \quad(k=1,2)
$$

となる。内部境界 $\Gamma_{I}$ 上の節点上のポテンシャル値、フラッ クス値に関して、次の適合条件、平衡条件

$$
\left.\begin{array}{c}
u_{I}^{1}=u_{I}^{2}=u_{I} \\
\mu_{1} q_{I}^{1}=-\mu_{2} q_{I}^{2}=\mu_{1} q_{I}
\end{array}\right\}
$$

を加味すると、式(21)、(22)より、

$$
\left[\begin{array}{rrrr}
\boldsymbol{H}^{1} & H_{I}^{1} & -G_{I}^{1} & \mathbf{0} \\
\mathbf{0} & H_{I}^{2} & \frac{\mu_{1}}{\mu_{2}} G_{I}^{2} & H^{2}
\end{array}\right]\left\{\begin{array}{r}
u^{1} \\
u_{I} \\
q_{I} \\
u^{2}
\end{array}\right\}=\left[\begin{array}{rr}
G^{1} & \mathbf{0} \\
0 & G^{2}
\end{array}\right]\left\{\begin{array}{l}
q^{1} \\
q^{2}
\end{array}\right\}
$$

のように合成マトリクス方程式を得ることができる。式 (23)を解き、末知数を得る。

初期要索分割とその飾点を選点として得た解を $\dot{u} 、 \hat{q}$ と おき、部分領域を含む境界要素解析に代表点祸差解析 法を通用する。境界条件として与えられた可には修正 量は必要ないことに注意して、内部境界 $\Gamma_{I} に$ 代表点が存 在するとき、修正量を加えると式(2)と同様に次のよう になる。

$$
c_{i}\left(p_{i}^{\prime}\right)\left\{\hat{u}\left(p_{i}^{\prime}\right)+e_{u}\left(p_{i}^{\prime}\right)\right\}=\int_{\Gamma}\left[\left(\hat{q}+e_{q}\right) u^{*}-q^{*}\left(\dot{u}+e_{u}\right)\right] d \Gamma
$$

式(3)、(5) 及び式(4)より、同様に $c_{i} \dot{u}_{i}\left(p_{i}^{\prime}\right)$ と $r\left(p_{i}^{\prime}\right)$ を定義 すると、 $p_{\mathrm{i}}^{\prime}$ が内部境界 $\Gamma_{I}$ 上に存在する場合は次式のよう になる。

$$
\begin{aligned}
r\left(p_{i}^{\prime}\right) & \equiv c_{i}\left(p_{i}^{\prime}\right)\left\{\hat{u}\left(p_{i}^{\prime}\right)-\dot{u}_{i}\left(p_{i}^{\prime}\right)\right\} \\
& =\int_{\Gamma_{u} \cup \Gamma_{I}} e_{q} u^{*} d \Gamma-\int_{\Gamma_{q} \cup \Gamma_{I}} e_{u} q^{*} d \Gamma-c_{i}\left(p_{i}^{\prime}\right) e_{u}\left(p_{i}^{\prime}\right)
\end{aligned}
$$

式(6)により式(24)を離散化すると、 
$\underline{p_{i}^{\prime} \in \Gamma_{I}}$

$r\left(p_{i}^{\prime}\right)=\sum_{j}^{n_{u}+n_{I}} \int_{\Gamma} u^{*} \Psi e_{q j} d \Gamma-\sum_{j}^{n_{j}+n_{I}} \delta_{i j} c_{i} e_{u i}-\sum_{j}^{n_{q}+n_{I}} \int_{\Gamma} q^{*} \Psi e_{u j} d \Gamma$

ここで $n_{I}$ は内部境界 $\Gamma_{I}$ 上に存在する要素の数であり、 $j \supseteq i(i=1, \cdots, N) 、 N=n_{u}+n_{q}+n_{I}$ となる。外部境界に ついて、不整合量と修正量の関係は式(8)、(9)と同粎と なる。式(8)、(9)および式(25)をマトリクス形式で書く と、 $\Omega_{k}$ の境界について

$$
r^{k}=A^{k} e^{k} \quad(k=1,2)
$$

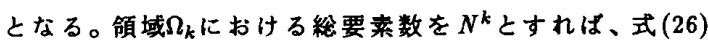
の左辺の列べクトルは、 $N^{k}$ 個の成分を持ち、次のよう に示される。

$$
r^{k} \equiv\left\{\begin{array}{c}
r_{u} \\
- \\
r_{q} \\
r_{I}
\end{array}\right\}=\left\{\begin{array}{c}
c\left\{\bar{u}\left(p_{i}^{\prime}\right)-\dot{u}\left(p_{i}^{\prime}\right)\right\} \\
------- \\
c\left\{\hat{u}\left(p_{i}^{\prime}\right)-\dot{u}\left(p_{i}^{\prime}\right)\right\} \\
c\left\{\hat{u}\left(p_{i}^{\prime}\right)-\dot{u}\left(p_{i}^{\prime}\right)\right\}
\end{array}\right\}
$$

式(26)の $A^{k}$ は趾差影筫マトリクスであり、 $\left(N^{k} \times\left(N^{k}+n_{I}^{k}\right)\right)$ の成分を持つ。

$$
\begin{aligned}
& \boldsymbol{A}^{k}=
\end{aligned}
$$

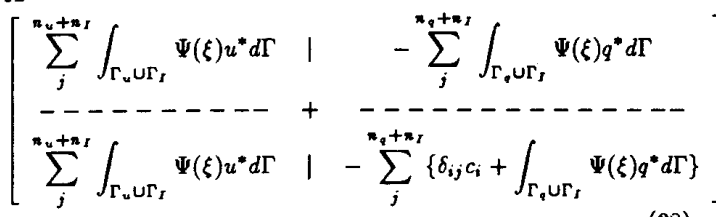

$e^{k}$ は要类における修正量（の最大值 $e_{u j} 、 e_{q j}$ )からなる 列べクトルであり、 $\Gamma_{I}$ 上の要素は $e_{u}$ と $e_{q}$ の両者が存在す るのて、合計 $N^{k}+n_{I}^{k}$ 個の成分を持っ。

$$
e^{k}=\left\{\begin{array}{c}
e_{q} \\
- \\
e_{u}
\end{array}\right\}
$$

式 (26) を内部境界 $\left(\Gamma_{l}\right)$ と外部境界 $\left(\Gamma_{u} \cup \Gamma_{q}\right)$ とに留意し て書き直すと、

$$
\left\{\begin{array}{l}
r_{o} \\
r_{I}
\end{array}\right\}=\left[\begin{array}{lll}
a_{11} & a_{12} & a_{13} \\
a_{21} & a_{22} & a_{23}
\end{array}\right]\left\{\begin{array}{l}
e_{o} \\
e_{u I} \\
e_{q I}
\end{array}\right\}
$$

ここでr。、r $\boldsymbol{r}_{I}$ それぞれ外部境界、内部境界上にンース 点 $p_{i}^{\prime}$ (代表点)が存在する時の不整合量ベクトルである。 $e_{0}$ は外部境界要索上の修正量（ポテンシャル、フラック スによる修正量のいずれも含む)べトルであり、昰、 $e_{q I}$ はそれぞれ内部境界要素上のポテンシャル修正至へ クトル、フラックス售正量ベクトルである。領域 $\Omega_{1} 、 \Omega_{2}$ に関して式(30)はそれそれ次式のようになる。

$$
\left\{\begin{array}{c}
r_{o}^{1} \\
r_{I}^{1}
\end{array}\right\}=\left[\begin{array}{lll}
a_{11}^{1} & a_{12}^{1} & a_{13}^{1} \\
a_{21}^{1} & a_{22}^{1} & a_{23}^{1}
\end{array}\right]\left\{\begin{array}{c}
e_{o}^{1} \\
e_{u I}^{1} \\
e_{q I}^{1}
\end{array}\right\} \quad\left(\Omega_{1}\right)
$$

$$
\left\{\begin{array}{l}
r_{o}^{2} \\
r_{I}^{2}
\end{array}\right\}=\left[\begin{array}{lll}
a_{11}^{2} & a_{12}^{2} & a_{13}^{2} \\
a_{21}^{2} & a_{22}^{2} & a_{23}^{2}
\end{array}\right]\left\{\begin{array}{c}
e_{o}^{2} \\
e_{u I}^{2} \\
e_{q I}^{2}
\end{array}\right\} \quad\left(\Omega_{2}\right)
$$

それぞれのベクトル、マトリクス成分の右罱の添え字 は、対応する領域を示している。したがって $r_{I}^{1}$ はンース 点が $\Omega_{1}$ の境界としての「厂たるるときの不整合量であり、 $r_{I}^{2}$ と区別される。

式(17)、(18) を満足する解の内部境界上のポテンシャ ル畐、フラックス量を $u_{\text {Iexact、 }} q_{\text {I exact }}$ する。領域 $\Omega_{1}$ 、領 域 $\Omega_{2}$ の境界線である内部境界上にでは適合条件及び平 衡条件が成立する。

$$
\left.\begin{array}{c}
u_{l_{\text {exact }}}^{1}=u_{\text {lexact }^{2}}^{2} \\
\mu_{1} q_{\text {Iexact }}^{1}=-\mu_{2} q_{\text {lexact }}^{2}
\end{array}\right\}
$$

また、式(22)より初期選点列 $\left\{p_{i}\right\}$ で求めた近似解におい ても通合条件及び平衡条件が成立しているので

$$
\left.\begin{array}{c}
\hat{u}_{I}^{1}=\hat{u}_{I}^{2} \\
\mu_{1} \hat{q}_{I}^{1}=-\mu_{2} \hat{q}_{I}^{2}
\end{array}\right\}
$$

となる。したがって修正量 $e_{\text {、、 }} e_{q}$ はそれぞれ次式の関係 で示される。

$$
\left.\begin{array}{l}
e_{u I}=u_{\text {Iexact }}-\hat{u}_{I} \\
e_{q I}=q_{\text {Iexact }}-\hat{q}_{I}
\end{array}\right\}
$$

式(33) 式(35)より、

$$
\left.\begin{array}{c}
e_{u I}^{1}=e_{u I}^{2}=e_{u I} \\
e_{q I}^{1}=-\frac{\mu_{2}}{\mu_{1}} e_{q I}^{2}=e_{q I}
\end{array}\right\}
$$

が得られる。式(36)を考慮し、式(31)式(32)を合成する と次のようになる。

$$
\left\{\begin{array}{l}
r_{o}^{1} \\
r_{I}^{1} \\
r_{I}^{2} \\
r_{o}^{2}
\end{array}\right\}=\left[\begin{array}{rrrr}
a_{11}^{1} & a_{12}^{1} & a_{13}^{1} & 0 \\
a_{21}^{1} & a_{22}^{1} & a_{23}^{1} & 0 \\
0 & a_{22}^{2} & -\frac{\mu_{1}}{\mu_{2}} a_{23}^{2} & a_{21}^{2} \\
0 & a_{12}^{2} & -\frac{\mu_{1}}{\mu_{2}} a_{13}^{2} & a_{11}^{2}
\end{array}\right]\left\{\begin{array}{l}
e_{o}^{1} \\
e_{u I} \\
e_{q I} \\
e_{o}^{2}
\end{array}\right\}
$$

式(37)は、未知数と式の数が一致し、左辺は既知である から、右辺のベクトルについて解くことができる。

$$
e=A^{-1} r
$$

\section{4 差䄈価とメッシュの細分割}

式(38)で得た俈正量は要素ごとの捛差の大きさを表 しており、これは境界条件に対応して、ポテンシャルて あったり、フラックスであったり、あるいは内部境界上で はその両者が存在する。したがって、これらの次元の異 なる量を相対的に比较することが困蜼であるから、こ れらを統一して报うために、誤差影韧マトリクスA内に 含まれる各器差に対灿する基本解を掛け合わせたるの 
（拡張誤差表示式）により、䛊差の影紫の度合いを表現 する。また、部分領域分割を含し問邀では、それぞれの 部分領域ことに誤差の度合いが䢖うので、領域間にお ける䛊差の影忞の速いを考えなけれはいけない。領域 $\Omega_{1}$ と領域 $\Omega_{2}$ は内部境界 $\Gamma_{I}$ より、結合されている。そこ て、それぞれの領域の境界における解が内部境界上の 解に与える影需は次式で表される(要素iは「厂上)。

$$
\left.\begin{array}{l}
\alpha^{1}=\sum_{i}^{n_{I}} \sum_{j}^{N^{1}} \eta_{i j}^{1} \\
\alpha^{2}=\sum_{i}^{n_{I}} \sum_{j}^{N^{2}} \eta_{i j}^{2}
\end{array}\right\}
$$

内部境界において要素分割は2つの領域に共通であるか ら、要菜数および節点数を合わせなければならない。こ こでは領域間の影䨘を式(39)で考感しながら要索分割 を行う。要素分割は、それぞれの領域䟽での $\eta_{i j}^{k}$ の值が基 準值福を超えたときに行うののとする。

$$
\eta_{i j}^{k}>\eta_{t o l}^{k}
$$

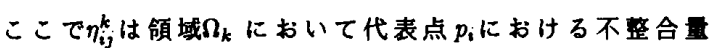

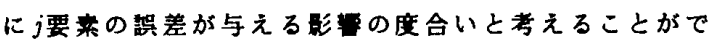

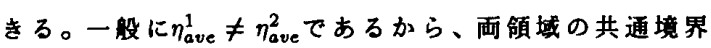

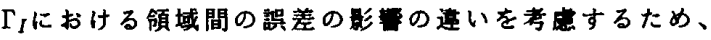
式 (39)を用いて $\eta_{t o l}^{k}$ を次のように定める。

$$
\left.\begin{array}{ll}
\alpha^{2}>\alpha^{1} \text { の時 } & \\
\alpha^{1}>\alpha^{2} \text { の時 } & \eta_{\text {tol }}^{1}=\frac{\alpha^{2}}{\alpha^{1}} \eta_{\text {ave }}^{1} \\
& \eta_{\text {ave }}^{1}
\end{array}\right\}
$$

式(41) 式(42)の様に場合分けが生じるのは h 法による メッシュ分割によって要素が週度に細分割されるのを防 ぐためである。

\section{5 数值解析甽}

これまで示してきた部分領域分割を含し 2 次元ボテン シャル問題における代表点誤差解析法を道用した解析侧 題を示す。解析例題 1 は同一物性值を持つ单一領域であ ろが、形状、寸法から考えて、しはししは領域分割を行っ て解析する例である。解析例題 2 では、2程類の材䆩か らなる領域の解析を行う。なお、解析に際しては、1次 要素を用い、フラックスの不連繶となる点においては完 全二重節点法を改良した方法を使用した。通常の数值積 分に際しては、ニュートンコーツ8 点䖽分公式に基ゔく アダブティブ程分を使用し、特異皘分は二重指数関数变 換に基づくアダブティフ積分、連立方程式の解法には、 LU分解を使用した。

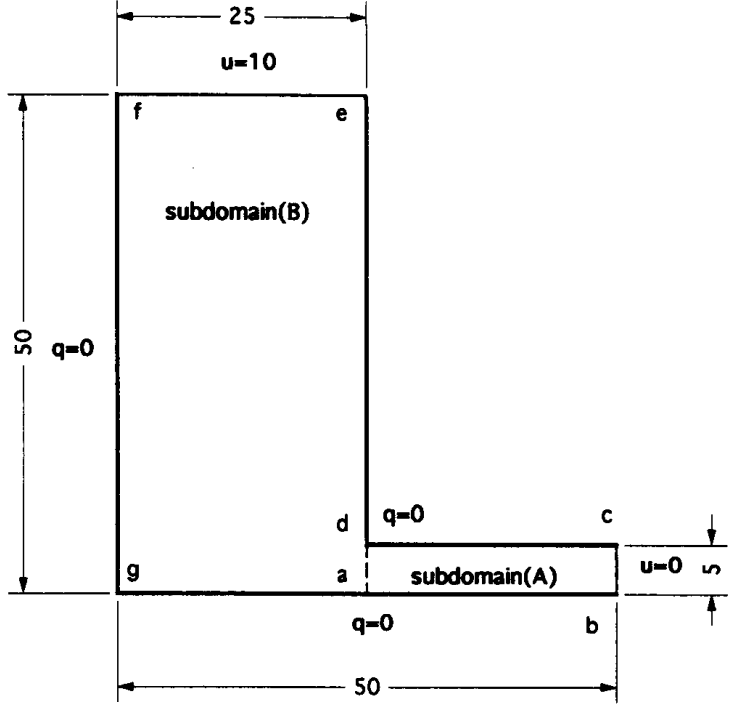

図2.解析例题 1：形状および境界条件

\section{1 解析国 1 L 字型颃域の問题}

图2 は、解析侧题 1 でとりあげた形状、寸法および境 界条件を示している。この問題の全領域を単一領域と して解析した場合を図3、4に示し、2領域に分割して解 析した埸合を図 5 と6に示す。なおここで用いるプログ ラムでは、数值皘分による誤差を極力さけるためにて ダプティブ積分をくりかえす方法を用いているので、方 向により寸法に大きい㟟いがあっても糐度のよい解を得 ることが確かめられている。図 3 および 5 の初期要菜・ 節点は問題を定载するために必要な最小数から計算を 行っている。図 4 が単一領域で 3 回の反復により得られ た結果であり、図 6 が 2 領域分割で 3 回の反復により得 られた結果である。両者とすよく一致する結果となって いる。したがって、いずれの方法でもよい精度の解を得 ることが可能であるが、それらの効率の比较が図7にな されている。この图は平均不整合量、最大不合量の丁 ダプティブ糟分の回数との関連を示したすのであり、单 一領域として扱うと計算回数が多く必要で、しかも不 整合量が、2 領域に分割した場合よりる大きくなってい ることがわかる。

\section{2 解析列题 22 程の材料加らなる艮方形颃域 の凬题}

図 8 は $\mu_{1}=1 、 \mu_{2}=0.5$ の 2 つの物性值からなる問題の 例である。この問題では 2 領域が必ず必要である。図 9 は初期要絭・節点の必要最小限にとったときのメッシュ とその解であり、図10は4 回の反復によって得たアタブ ティブメッシュと対応する解である。この解は初期メッ 

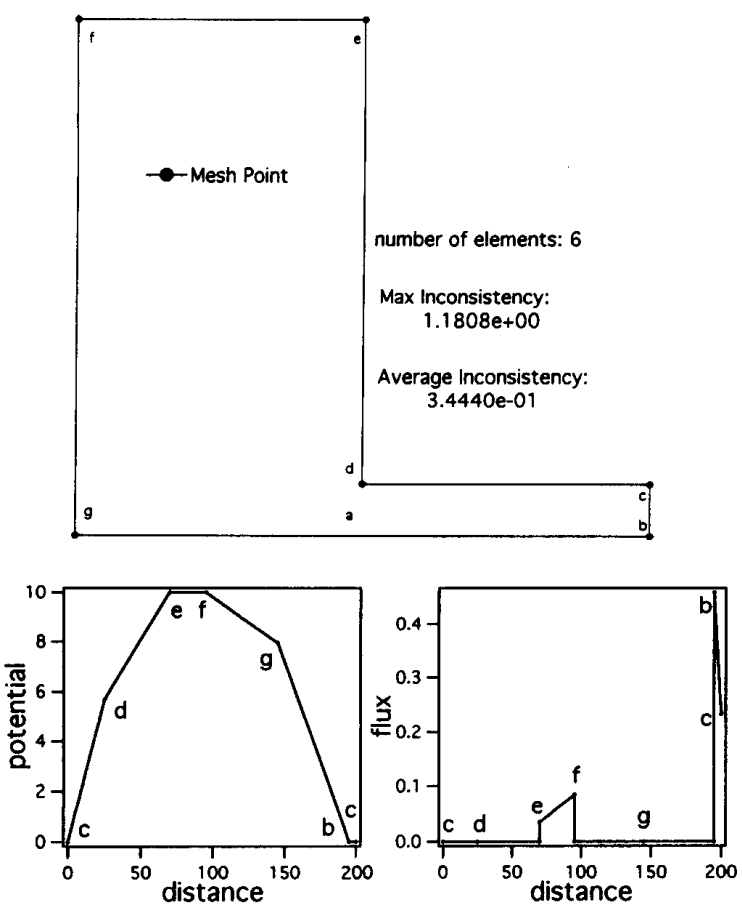

図3. 初期メッシュと解 (単一領域)
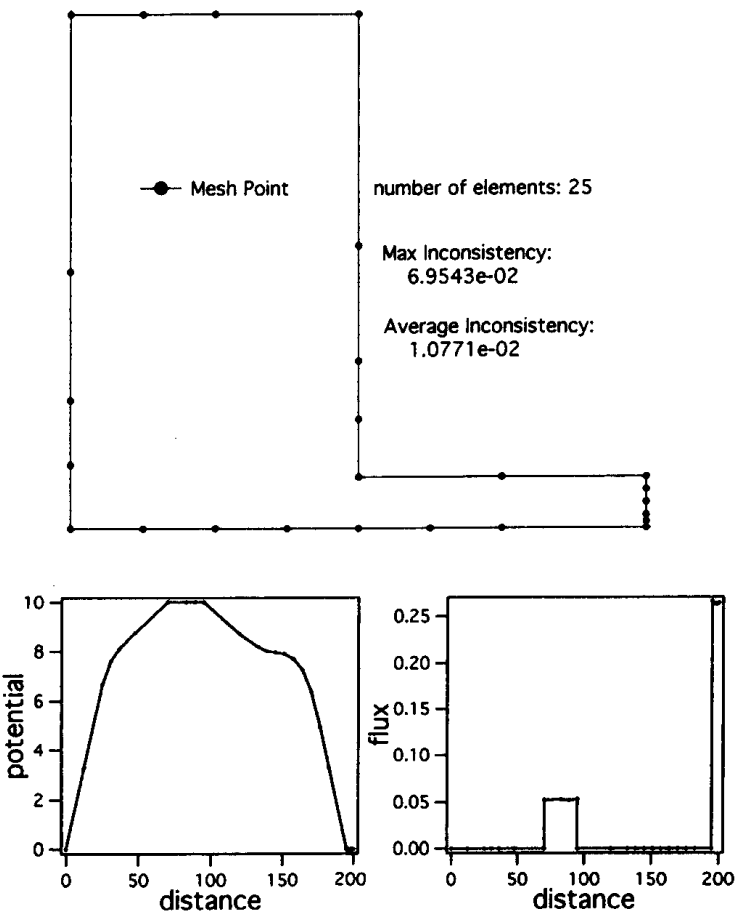

図 4. 3 回反復後のメッシニと解 (単一領域)
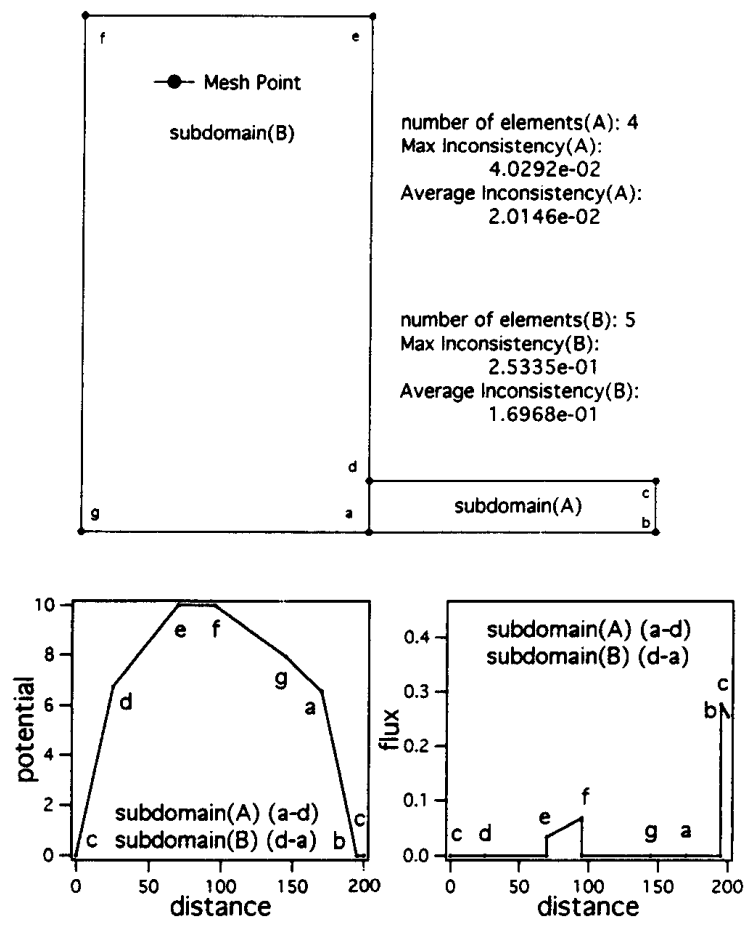

図 5. 初期メッシュと解 (2 領域部分分割)
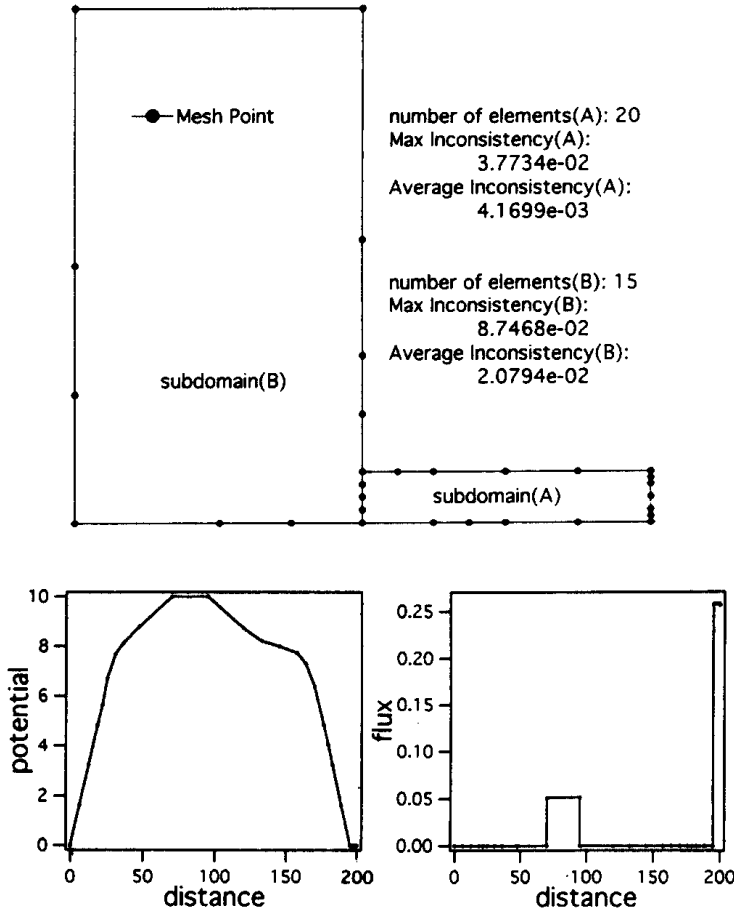

困6. 3 回反復後のメッシュと解 (2 領域部分分割) 

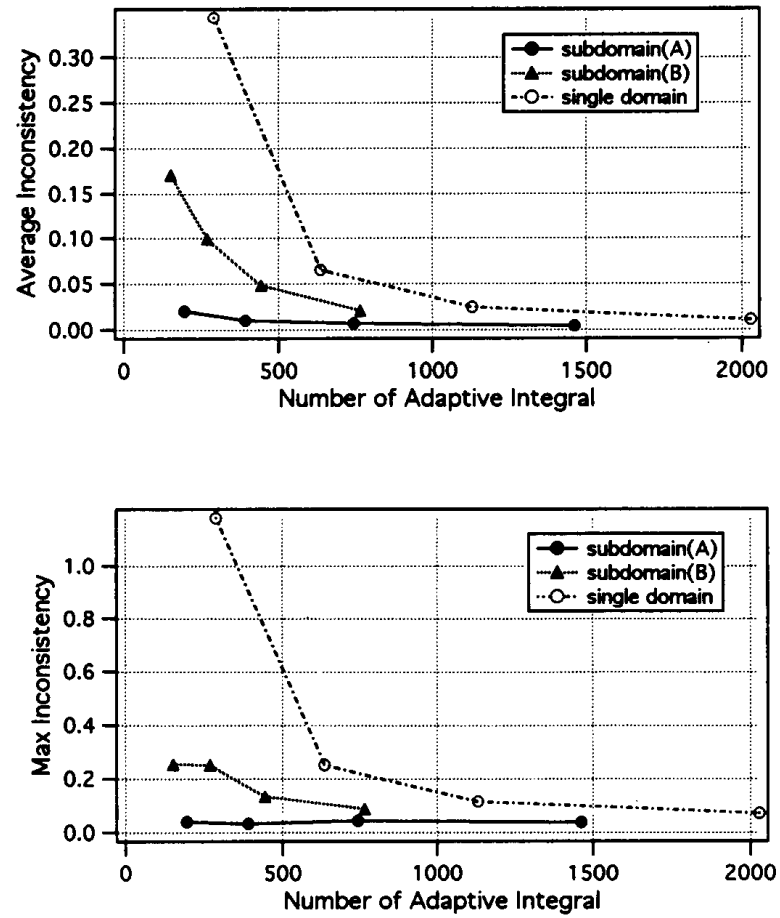

図 7. 不整合量とアダブティブ䅡分回数

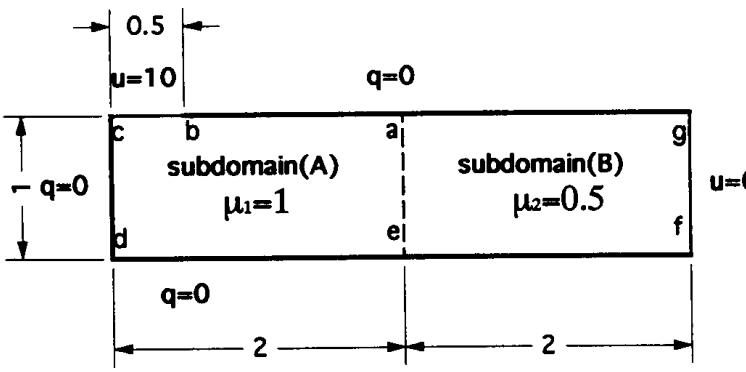

図8. 鲜析例題 2: 形状および境界条件

シュを極めて細かくとった解とよい一致をすることを確 認した。

\section{6 まとめ}

前に提案した代表点誤差解析法に基づく、アダブティ ブ要素椿成法を、領域分割を必要とするBEM 解析に拡 張した。内部境界は 2 つ部分領域に共通であるので、 この部分の要素分割の度合いが双方の部分領域ことに異 なる点を、1つのパラメー夕を導入して調節する方法を 示した。2次元ラプラス方程式に関連する例題として、 通常部分分割を行う単一領域の問題および異種材料によ る2領域の問題を解析し、本方法の有効性を確認した。
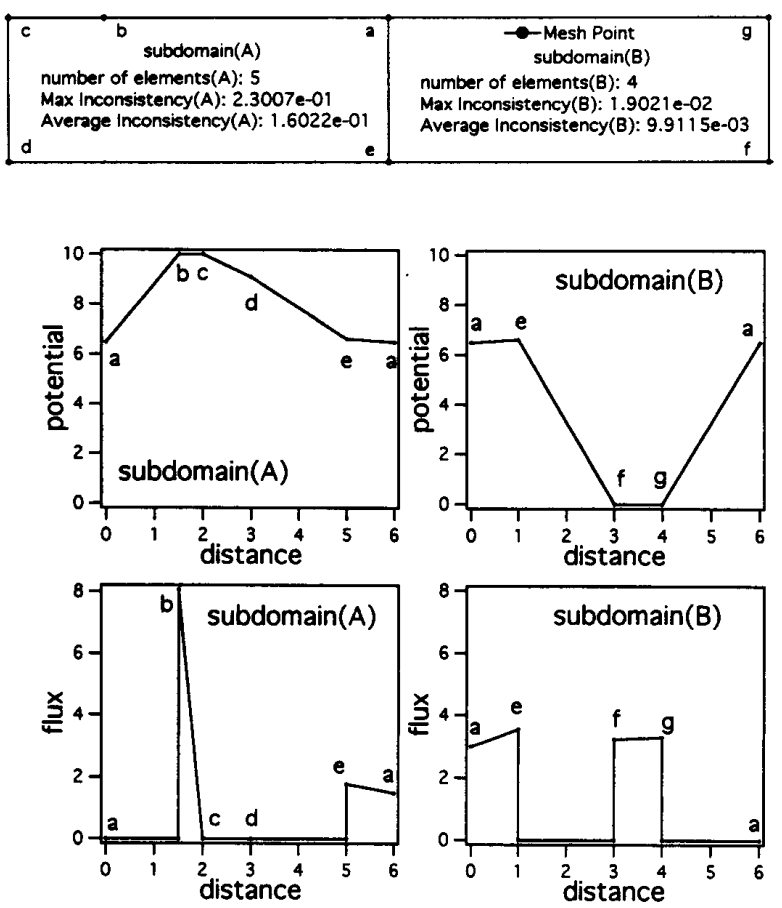

図9. 初期メッシュと解
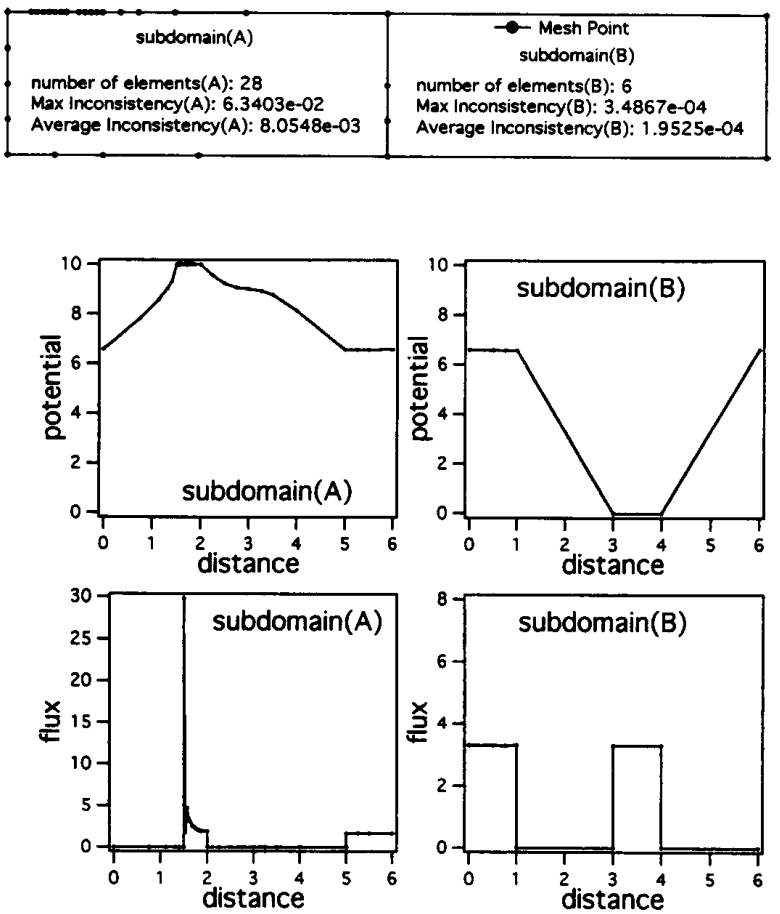

図104回反復後のメッシュと解 


\section{考文神}

[1] E.Alarcon and A.Reverter, p-adaptive boundary elements, Int. J. Num. Meth. Eng., Vol.23, pp.801-829, 1986.

[2] J.J.Rencis and K.Y.Jong, A self-adaptive h-refinemnt technique for the boundary element method, Comp. Meth. Appl. Mech. Eng., Vol.73, pp.295-316, 1989.

[3] E.Rank, Adaptive $h, p$ and $h p$ versions for boundary integral element methods, Int. J Num. Meth. Eng., Vol.28, pp.1335-1349, 1989.

[4] 佐々木・掼山，境界要亲解析における精度保証のた めの遭応的自趿要㭉分割技法，日本機械学会詥文集，
A55, 1416-1422, 1989.

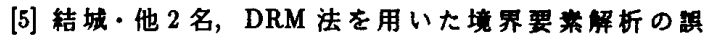
差評価手法, 境界要素法論文菓 第 6 巻, pp.131-136, 1989.

[6] M.Guiggiani, Error indicators for adaptive mesh refinement in the boundary element methods - A new approach, Int. J. Num. Meth. Eng. ,Vol.29, 1247-1269, 1990.

[7] 川ロ・神谷, 代表点路差解析によるアダブティブ BEM, 日本機珹学会諭文集, A56, 2032-2039，1990.

[8]川口・神谷, 聯性解析のための直地境界要亲, 日本 機械学会諭文集，A56，2501-2507，1990. 